\title{
Editorial
}

\section{Lessons From Outbreaks Associated With Bronchoscopy}

\author{
David J. Weber, MD, MPH; William A. Rutala, PhD, MPH
}

Bronchoscopy is currently the most commonly employed invasive procedure in the practice of pulmonary medicine. ${ }^{1}$ An estimated 497,000 bronchoscopy procedures were performed in the United States in $1996 .{ }^{2}$ Current and new applications include bronchoscopic ultrasound, laser therapy, brachytherapy, electrocautery, cryotherapy, placement of airway stents, and balloon dilatation to relieve airway obstruction caused by airway lesions. ${ }^{3}$ Flexible endoscopes also are widely used in other medical disciplines. For example, more than $10,000,000$ gastrointestinal endoscopies are performed each year. ${ }^{4}$

Endoscopes represent the medical devices most commonly linked to nosocomial outbreaks and pseudooutbreaks. ${ }^{5}$ Flexible endoscopes present a challenge for low-temperature sterilization or high-level disinfection, because they have long narrow lumens, cross-connections, mated surfaces, sharp angles, springs and valves, occluded dead ends, absorbent material, and rough or pitted surfaces. ${ }^{6,7}$ Failure to eradicate contamination that occurred during use may lead to person-to-person transmission of pathogens (eg, Mycobacterium tuberculosis); failure to prevent contamination during disinfection or storage may lead to outbreaks or pseudo-outbreaks from environmental microbes (eg, nontuberculous mycobacteria, or Rhodotorula rubra). In this issue, Sorin and colleagues ${ }^{8}$ describe the nosocomial transmission of an imipenemresistant strain of Pseudomonas aeruginosa, and Kressel and Kidd $^{9}$ describe a pseudo-outbreak involving organisms relatively resistant to glutaraldehyde (ie, Mycobacterium chelon$a e$ and Methylobacterium mesophilicum) associated with the use of contaminated bronchoscopes.
Prevention of endoscope-related infections requires strict adherence to current guidelines for cleaning and disinfection. Guidelines for disinfection of flexible endoscopes, including bronchoscopes, have been published by the Association for Professionals in Infection Control and Epidemiology, Inc. ${ }^{10,11}$ To date, nosocomial outbreaks have not been reported in which all current recommendations were followed scrupulously. These guidelines are based on sound scientific principles generated from several sources of data: first, studies on the natural bioburden of endoscopes and efficacy of cleaning; second, studies on the in vitro efficacy of recommended high-level disinfectants and low-temperature sterilization methods; third, studies of disinfection of simulated endoscopes or experimentally inoculated endoscopes; fourth, studies of the effectiveness of current high-level disinfection and sterilization methods in actual practice; and finally, lessons learned from outbreaks and pseudo-outbreaks involving endoscopes.

Only limited data are available on the bioburden present on bronchoscopes following use. Alfa and Sitter reported the average load on bronchoscopes before cleaning was $6.4 \times 10^{4}$ colony-forming units (CFUs) $/ \mathrm{mL}$, with streptococci and normal upper respiratory flora being reported. ${ }^{12}$ The bioburden on used gastrointestinal endoscopes is higher, ranging from $10^{6}$ to $10^{7} \mathrm{CFUs}$ for upper gastrointestinal endoscopes and $10^{8}$ to $10^{10} \mathrm{CFUs}$ for colonoscopes. ${ }^{13}$ Cleaning has been demonstrated to reduce the bioburden on endoscopes in most studies by more than 4 logs. ${ }^{13}$ Cleaning also removes organic and inorganic debris that may compromise the disinfection and sterilization process. For example, Alfa and colleagues tested several low-temperature sterilization methods (ie, ethylene

From the Division of Infectious Diseases, University of North Carolina (UNC) School of Medicine, and the Department of Hospital Epidemiology, UNC Health Care System, Chapel Hill, North Carolina.

Address reprint requests to David J. Weber, MD, MPH, CB \#7030 Burnett-Womack, 547, University of North Carolina at Chapel Hill, Chapel Hill, NC 27599-7030.

The authors have received no research funds from sterilizer manufacturers, but one of the authors (WAR) received honoraria from a sterilizer manufacturer in the past 12 months.

00-ED-056. Weber DJ, Rutala WA. Lessons from outbreaks associated with bronchoscopy. Infect Control Hosp Epidemiol 2001;22:403-408. 
TABLE 1

Steps in the Disnffection Process and Mechanisms for Failure

\begin{tabular}{|c|c|c|}
\hline Disinfectlon Component & Reasons tor Component & Mechanisms for Fallure \\
\hline Cleaning & Reduce bioburden & Inadequate policies \\
\hline & Remove interfering substances: blood, salt & Inadequate staff training \\
\hline Appropriate disinfectant & $\begin{array}{l}\text { Inactivation of contaminating microbes } \\
\text { (demonstrated efficacy and effectiveness) }\end{array}$ & $\begin{array}{l}\text { Ineffective disinfectant } \\
\text { Inadequate concentration } \\
\text { Inadequate duration }\end{array}$ \\
\hline $\begin{array}{l}\text { Contact between disinfectant and } \\
\text { contaminating microbes }\end{array}$ & Requirement for killing & $\begin{array}{l}\text { AER: failure to use channel connectors } \\
\text { AER: wrong channel connectors } \\
\text { Occluded lumen } \\
\text { Torn or damaged lumen }\end{array}$ \\
\hline Sterilization of biopsy forceps & Eliminate contaminating microbes & $\begin{array}{l}\text { Inadequate policies } \\
\text { Inadequate staff training }\end{array}$ \\
\hline Rinse & $\begin{array}{l}\text { Remove potentially toxic chemicals } \\
\text { (eg, glutaraldehyde, hydrogen peroxide) }\end{array}$ & $\begin{array}{l}\text { Mucous membrane damage } \\
\text { (eg, colitis) }\end{array}$ \\
\hline Prevention of recontamination & $\begin{array}{l}\text { Prevent contamination with environmental } \\
\text { microbes }\end{array}$ & $\begin{array}{l}\text { Tap water rinse without subsequent } \\
\text { alcohol rinse } \\
\text { Failure to air dry scope } \\
\text { Contaminated AER } \\
\text { Placement of scope in contaminated } \\
\quad \text { container }\end{array}$ \\
\hline
\end{tabular}

oxide, hydrogen peroxide gas plasma, and vaporized hydrogen peroxide) and reported that none could eradicate $10^{6} \mathrm{CFUs}$ of all bacterial strains inoculated on a carrier placed in a narrow lumen in the presence of $10 \%$ serum and $0.65 \%$ salt. $^{14}$

Currently, the Food and Drug Administration has cleared several chemical sterilants listed as high-level disinfectants for reprocessing endoscopes. ${ }^{15}$ These include: $\geqslant 2.4 \%$ glutaraldehyde, $0.55 \%$ ortho-phthalaldehyde, a $0.95 \%$ glutaraldehyde with $1.64 \%$ phenol/phenate, $1.0 \%$ hydrogen peroxide with $0.08 \%$ peracetic acid, $7.35 \%$ hydrogen peroxide with $0.23 \%$ peracetic acid, and $7.5 \%$ hydrogen peroxide. ${ }^{15,16}$ Although all of these products have excellent antimicrobial activity, $7.5 \%$ hydrogen peroxide and $1.0 \%$ hydrogen peroxide with $0.08 \%$ peracetic acid have limited use, because they cause cosmetic and functional damage to the endoscope. The two products most commonly used for reprocessing endoscopes in the United States are glutaraldehyde and the automated chemical sterilization process that uses peracetic acid (STERIS SYSTEM 1, Mentor, $\mathrm{OH}) .{ }^{17}$ The advantages and disadvantages of the chemical sterilant, peracetic acid (STERIS SYSTEM 1), and high-level disinfection methods have been reviewed. ${ }^{7}$

The importance of allowing the sterilant to come into contact with an inoculated carrier has been demonstrated by two studies that investigated the peracetic acid immersion system (ie, STERIS SYSTEM 1). Alfa and coworkers demonstrated excellent activity of the peracetic acid immersion system against three test organisms using a narrow-lumen device..$^{18}$ In these experiments, the lumen test object was connected to channel connectors, which ensured that the sterilant had direct contact with contami- nated carriers. The effectiveness was achieved by the combination of organism wash-off and peracetic acid inactivation of the test organisms. Data reported by Rutala and colleagues demonstrated failure of the peracetic acid immersion system to eliminate Bacillus stearothermophilus spores completely from an inoculated carrier placed in a stainless steel lumen test unit. ${ }^{19}$ In these experiments, the lumen test unit was not connected to channel connectors. The failure of the peracetic immersion system was felt to be attributed to the inability of the peracetic acid to diffuse into the center of a $40-\mathrm{cm}$-long, 3-mm-diameter tube, possibly due to an air lock or air bubble formed in the lumen that would impair flow. ${ }^{20,21}$ We have since repeated our experiments using a channel connector specially designed for our 1-, 2-, and 3-mm lumen test units, with the result that the STERIS SYSTEM 1 was completely effective in eliminating an inoculum of $10^{6} \mathrm{~B}$ stearothermophilus spores (WAR, unpublished data, October 2000). Both Sorin and colleagues ${ }^{8}$ and Kressel and Kidd ${ }^{9}$ demonstrate the clinical relevance of these findings.

Experimental contamination of flexible bronchoscopes with Mycobacterium gordonae ${ }^{22}$ and gastrointestinal endoscopes with duck hepatitis $B$ virus ${ }^{23}$ has demonstrated the importance of cleaning and validated current disinfection recommendations. The importance of cleaning also has been demonstrated in studies evaluating gastrointestinal endoscopes contaminated with Helicobacter pylori. ${ }^{24}$ Simulated-use trials with the STERIS SYSTEM 1 have demonstrated excellent microbicidal activity, and three clinical trials have demonstrated both excellent microbial killing and no clinical failure leading to infection. ${ }^{7}$

Failure to follow current disinfection recommendations (Table 1) has led to multiple outbreaks ${ }^{8,2535}$ (Table 2) 
TABLE 2

Nosocomial OUtbreaks via Bronchoscopes due to Exogenous Contamination or Person-to-Person TRANSMISSION

\begin{tabular}{|c|c|c|c|}
\hline Reference & Yoar & Pathogen* & Mechanism of Contamination \\
\hline Webb et $\mathrm{al}^{25}$ & 1975 & Serratia marcescens & Inadequate disinfectant (70\% alcohol) \\
\hline Hussain ${ }^{26}$ & 1978 & Pseudomonas & Contaminated biopsy suction attachment (soaked in antiseptic) \\
\hline Markovitz 27 & 1979 & Pseudomonas pseudomallei & Not specified \\
\hline Leers $^{28}$ & 1980 & Mycobacterium tuberculosis & Inadequate cleaning and disinfectant (povidone-iodine) \\
\hline Nelson et $\mathrm{al}^{29}$ & 1983 & $M$ tuberculosis & Inadequate disinfectant (povidone-iodine/70\% ethanol) \\
\hline Pappas $^{30}$ & 1983 & Mycobacterium chelonei & Two bronchoscopes with punctured suction channels \\
\hline Wheeler et $\mathrm{al}^{31}$ & 1989 & $M$ tuberculosis & Contaminated suction valve \\
\hline Agerton et $\mathrm{al}^{32}$ & 1997 & MDR $M$ tuberculosis & $\begin{array}{l}\text { Inadequate cleaning, failure to use leak-test equipment, no potency testing } \\
\text { of glutaraldehyde, failure to immerse scope fully, terminal tap water } \\
\text { without subsequent alcohol rinse }\end{array}$ \\
\hline Blanc et $\mathrm{al}^{33}$ & 1997 & Pseudomonas aeruginosa & AER: contaminated unit \\
\hline Michele et $\mathrm{al}^{34}$ & 1997 & M tuberculosis & $\begin{array}{l}\text { Failure to use enzymatic cleaner, immerse scope fully, or sterilize biopsy } \\
\text { forceps }\end{array}$ \\
\hline Kramer et al ${ }^{35}$ & 2001 & $P$ aeruginosa & $\begin{array}{l}\text { AER: contaminated disinfectant ( } 0.04 \% \text { glutaraldehyde) due to inadequate } \\
\text { concentration (concentration mistakenly set too low) }\end{array}$ \\
\hline Sorin et $\mathrm{al}^{8}$ & 2001 & $P$ aeruginosa & AER: inappropriate channel connectors \\
\hline
\end{tabular}

Abbreviations: AER, automatic endoscope reprocessor; MDR, multidrug-resistant.

* Species as listed by investigator; may not reflect current taxonomy.

and pseudo-outbreaks ${ }^{9,36-64}$ (Table 3) involving bronchoscopes. The pathogen most commonly associated with outbreaks has been $M$ tuberculosis, a finding that is not surprising in that only bacteria endospores are relatively more resistant than mycobacteria to disinfectants. Outbreaks associated with automatic endoscope reprocessors (AERs) commonly involve $P$ aeruginosa, as was the case with the report by Sorin and colleagues. ${ }^{8}$ Pseudo-outbreaks most commonly involve nontuberculous mycobacteria or other water-derived environmental microbes such as Legionella, $R$ rubra, and $P$ aeruginosa. Pseudo-outbreaks also have resulted from use during bronchoscopy of contaminated medications or devices. ${ }^{65}$ For example, pseudo-outbreaks have resulted from the use of an anesthetic contaminated with $M$ gordonae ${ }^{66}$ or fungi, ${ }^{67}$ and atomizers contaminated with nontuberculous mycobacteria ${ }^{68}$ or $M$ tuberculosis. ${ }^{69}$

Lessons learned from outbreaks reported in the literature include the following. First, cleaning must precede disinfection or sterilization. Second, ineffective disinfectants such as iodophors, $30 \%$ to $70 \%$ alcohol, or inadequate concentrations of disinfectant may result in outbreaks. Third, contact of all internal and external surfaces with the disinfectant is crucial. Outbreaks have resulted from failure to immerse the scope fully, disassemble valves, or repair rips or tears in internal channels. The outbreak reported by Sorin and coworkers ${ }^{8}$ and pseudo-outbreaks reported in the literature ${ }^{61,62,64}$ suggest that the proper use of channel connectors to ensure flow through an endoscope's inner channels is essential. If an AER is used, one must ensure that all channel connectors are attached according to the AER's manufacturer. Fourth, following disinfection, a sterile water rinse followed by forced-air drying or a tap water rinse followed by forced-air drying and a 70\% alcohol rinse must be used to prevent recontamination. The disinfected endoscope must be stored so as to prevent recontamina- tion. Failure to rinse the scope fully also may result in mucositis following use of the scope on another patient, if either glutaraldehyde $\mathrm{e}^{70}$ or hydrogen peroxide is used as the disinfectant. AERs offer several advantages to manual reprocessing, including automation and standardization of several important reprocessing steps, ${ }^{71-73}$ which reduce the likelihood that an essential reprocessing step will be skipped, and reduction of personnel exposure to high-level disinfectants. However, failure of AERs has been linked to bronchoscopy-related outbreaks (Table 2) and pseudooutbreaks (Table 3), in part because the water filtration system may not reliably be able to provide sterile rinse water ${ }^{74}$ It is critical that personnel rigorously adhere to the current recommendations for the use of AERs. ${ }^{11} \mathrm{We}$ agree with Sorin and colleagues that random bacterial surveillance cultures of endoscopes to assure appropriate disinfection should be done as part of a comprehensive program in quality assurance.

In conclusion, there is a need for further development and redesign of AERs ${ }^{75}$ and endoscopes, ${ }^{6}$ so that they do not represent a potential source for infection. Newly developed disposable-component endoscope systems may be able to improve the ease of cleaning and disinfection and so reduce the risk of infection. Recommendations for the cleaning and disinfection of endoscopic equipment should be followed strictly. Unfortunately, audits have shown endoscopic personnel often fail to adhere to guidelines on disinfection. ${ }^{76-78}$ To ensure that persons responsible for reprocessing are properly trained, there should be initial and annual competency testing for such personnel. ${ }^{79,80}$

\section{REFERENCES}

1. Ahmad M, Dweik RA. Future of flexible bronchoscopy. Clin Chest Med 1999;20:1-17.

2. Center for Disease Control and Prevention. Vital and health statistics: ambulatory and inpatient procedures in the United States, 1996. DHHS 
TABLE 3

Nosocomial Pseudo-Outbreaks via Bronchoscopes due to Exogenous Contamination or Person-to-Person Transmission

\begin{tabular}{|c|c|c|c|}
\hline Reference & Year & Pathogen* & Mechanlsm of Contamination \\
\hline Weinstein et a ${ }^{36}$ & 1977 & Proteus species & Inadequate disinfection ( $30 \%$ alcohol) \\
\hline Dawson et $a^{37}$ & 1982 & Mycobacterium intracellulare & Inadequate disinfection of plastic tubing for collecting specimens \\
\hline Sammartino et $\mathrm{al}^{38}$ & 1982 & Pseudomonas aeruginosa & Inadequate disinfectant (povidone-iodine) \\
\hline Goldstein and Abrutyn ${ }^{39}$ & 1985 & Bacillus species & Contaminated automatic suction valve \\
\hline Siegman-Igra et al ${ }^{40}$ & 1985 & Serratia marcescens & Inadequate disinfection (alcohol) \\
\hline Richardson et al ${ }^{41}$ & 1986 & Bacillus species & Contaminated suction valves, terminal tap water rinse \\
\hline Hoffmann et al ${ }^{42}$ & 1989 & Rhodotorula rubra & Contaminated channel cleaning brushes and leak-test tub water \\
\hline Wheeler et $\mathrm{al}^{31}$ & 1989 & Mycobacterium avium & Contaminated suction valve \\
\hline Nye et $a^{43}$ & 1990 & Mycobacterium chelonae & Contaminated tap water rinse \\
\hline Fraser et al ${ }^{45}$ & 1992 & $M$ chelonae & $\begin{array}{l}\text { AER: contaminated AER. No terminal ethanol rinse and scopes not } \\
\text { forced-air dried }\end{array}$ \\
\hline Gubler et al ${ }^{46}$ & 1992 & $M$ chelonae & AER: contaminated AER \\
\hline Nicolle et a ${ }^{47}$ & 1992 & Blastomyces dermatitidis & Inadequate disinfection of bronchoscope \\
\hline Whitlock et $\mathrm{al}^{48}$ & 1992 & R rubra & Failure to air dry scope, contamination of suction and biopsy valves \\
\hline Bryce et al ${ }^{49}$ & 1993 & Mycobacterium tuberculosis & AER: contaminated suction valves and faulty wash/disinfect switch \\
\hline Vandernbroucke-Grauls et al ${ }^{50}$ & 1993 & $S$ marcescens & $\begin{array}{l}\text { Inadequate immersion time ( } 2 \mathrm{~min}) \text {, terminal tap water rinse, stored } \\
\text { without drying }\end{array}$ \\
\hline Bennett et $\mathrm{al}^{5 t}$ & 1994 & Mycobacterium xenopi & $\begin{array}{l}\text { Inadequate disinfectant ( } 0.13 \% \text { glutaraldehyde-phenate) and exposure } \\
\text { time, rinsed with contaminated tap water, inadequate drying }\end{array}$ \\
\hline Campagnaro et al $^{52}$ & 1994 & $M$ chelonae & AER: contaminated suction valve, terminal tap water rinse \\
\hline Kolmos et al ${ }^{53}$ & 1994 & Paeruginosa & $\begin{array}{l}\text { Failure to clean suction and biopsy channels, inexperienced bronchoscopy } \\
\text { staff }\end{array}$ \\
\hline Maloney et $\mathrm{al}^{54}$ & 1994 & Mabscessus & AER: contaminated AER \\
\hline Petersen et $\mathrm{al}^{55}$ & 1994 & Mabscessus & AER: contaminated AER \\
\hline Hagan et a ${ }^{56}$ & 1995 & $R$ rubra & Contaminated suction channel, inadequate drying \\
\hline Takigawa et al ${ }^{57}$ & 1995 & $M$ chelonae & AER \\
\hline Wang et al ${ }^{58}$ & 1995 & $M$ chelonae & AER: contaminated suction channel \\
\hline Mitchell et $\mathrm{a}^{159}$ & 1997 & Legionella pneumophila & Use of contaminated tap water for rinse, failure of $70 \%$ ethanol flush \\
\hline Wallace et al ${ }^{60}$ & 1998 & Mabscessus & AER and manual disinfection procedure \\
\hline Wallace et al ${ }^{60}$ & 1998 & Mabscessus & AER \\
\hline Wallace et a ${ }^{60}$ & 1998 & Mycobacterium fortuitum & AER \\
\hline $\mathrm{CDC}^{61}$ & 1999 & $M$ tuberculosis & AER: failure to replace biopsy port cap before loading in AER \\
\hline $\mathrm{CDC}^{61}$ & 1999 & $\begin{array}{l}\text { Mycobacterium avium- } \\
\text { intracellulare }\end{array}$ & $\begin{array}{l}\text { AER: use of channel connectors provided by bronchoscope } \\
\text { manufacturer rather than connector kit produced by AER } \\
\text { manufacturer }\end{array}$ \\
\hline Strelczyk ${ }^{62}$ & 1999 & Acid-fast bacilli & $\begin{array}{l}\text { AER: inadequate channel connectors provided by bronchoscope } \\
\text { manufacturer }\end{array}$ \\
\hline Wilson et $\mathrm{al}^{63}$ & 2000 & Aureobasidium species & Reuse of single-use stopcocks disinfected by an AER \\
\hline Larson et $\mathrm{ll}^{64}$ & 2001 & $M$ tuberculosis & AER: errors in cleaning, incompatible AER \\
\hline Kressel and Kidd ${ }^{9}$ & 2001 & $\begin{array}{l}\text { M chelonae, } \\
\text { Methylobacterium } \\
\text { mesophilicum }\end{array}$ & $\begin{array}{l}\text { AER: biofilm buildup in AER, no alcohol flush, organisms relatively } \\
\text { resistant to glutaraldehyde }\end{array}$ \\
\hline
\end{tabular}

Abbreviations: AER, automatic endoscope reprocessor; CDC, Centers for Disease Control and Prevention.

* Species as listed by investigator, may not reflect current taxonomy.

publication no. 99-1710. Hyattsville, MD: US Department of Health and Human Services, National Center for Health Statistics; 1998.

3. Prakash UB. Advances in bronchoscopic procedures. Chest 1999;116:1403-1408.

4. American Society for Gastrointestinal Endoscopy. Reprocessing of Flexible Gastrointestinal endoscopes. Manchester, MA: American Society for Gastrointestinal Endoscopy; 1995.

5. Spach DH, Silverstein FE, Stamm WE. Transmission of infection by gastrointestinal endoscopy and bronchoscopy. Ann Intern Med 1993;118:117-128.

6. Bond WW. Endoscopy reprocessing: problems and solutions. In: Rutala
WA, ed. Disinfection, Sterilization and Antisepsis in Health Care Champlain, NY: Polyscience Publications; 1998:151-163.

7. Rutala WA, Weber DJ. Disinfection of endoscopes: review of new chemical sterilants used for high-level disinfection. Infect Control Hosp Epidemiol 1999;20:69-76.

8. Sorin M, Segal-Maurer S, Mariano N, Urban C, Combest A, Rahal JJ. Nosocomial transmission of imipenem-resistant Pseudomonas aerugi nosa following bronchoscopy associated with an improper connection to the STERIS SYSTEM 1 processor. Infect Control Hosp Epidemiol 2001;22:409-413.

9. Kressel AB, Kidd F. A pseudo-outbreak of Mycobacterium chelonae 
and Methylobacterium meosphilicum caused by contamination of an automated endoscope washer. Infect Control Hosp Epidemiol 2001;22:414-418.

10. Rutala WA. APIC guideline for selection and use of disinfectants. Am J Infect Control 1996;24:313-342.

11. Alvarado CJ, Reichelderfer M, APIC Guidelines Committee. APIC guideline for infection prevention and control in flexible endoscopy. $A m J$ Infect Control 2000;28:138-155.

12. Alfa MJ, Sitter DL. In-hospital evaluation of ortho-phthalaldehyde as a high level disinfectant for flexible endoscopes. J Hosp Infect 1994;26:1526.

13. Roberts CG. Studies on the bioburden of medical devices and the importance of cleaning. In: Rutala WA, ed. Disinfection, Sterilization and Antisepsis: Principles and Practices in Healthcare Facilities. Champlain, NY: Polyscience Publications; 2001:63-69.

14. Alfa MJ, DeGagne P, Olson N, Puchalski T. Comparison of ion plasma, vaporized hydrogen peroxide, and $100 \%$ ethylene oxide sterilizers to the 12/88 ethylene oxide gas sterilizer. Infect Control Hosp Epidemiol $1996 ; 17: 92-100$.

15. US Food and Drug Administration. Sterilants and high level disinfectants cleared by FDA in a $510(\mathrm{k})$ as of June 29,2001 , with general claims for processing reusable medical and dental devices. http://www.fda.gov/cdrh/ode/germlab.html. updated July 2, 2001.

16. Rutala WA, Weber DJ. Infection control: the role of disinfection and sterilization. J Hosp Infect 1999;43(suppl):S43-S55.

17. Cheung RJ, Ortiz D, Dimarino AJ Jr. GI endoscopic reprocessing practices in the United States. Gastrointest Endosc 1999;50:362-368.

18. Alfa MJ, Olson N, DeGagne P, Hizon R. New low temperature sterilization technologies: microbiocidal activity and clinical efficacy. In: Rutala WA ed. Disinfection, Sterilization, and Antisepsis in Health Care. Washington DC: Association for Professionals in Infection Control and Epidemiology; 1998.

19. Rutala WA, Gergen MF, Weber DJ. Comparative evaluation of the sporicidal activity of new low-temperature sterilization technologies: ethylene oxide, 2 plasma sterilization systems, and liquid peracetic acid. $A m J$ Infect Control 1998;26:393-398.

20. Alfa MJ. Importance of lumen flow in liquid chemical sterilization (letter). Am J Infect Control 1999;27:373-374.

21. Rutala WA, Gergen MF, Weber DJ. Importance of lumen flow in liquid chemical sterilization (reply). Am J Infect Control 1999;27:374-375.

22. Jackson J, Leggett JE, Wilson D, Gilbert DN. Mycobacterium gordonae in fiberoptic bronchoscopes. Am I Infect Control 1996;24:19-23.

23. Deva AK, Vickery K, Zou J, West RH, Harris JP, Cossart YE. Establishment of an in-use testing method for evaluating disinfection of surgical instruments using the duck hepatitis B model. $J$ Hosp Infect 1996:33:119-130

24. Wu MS, Wang JT, Yang JC, Wang HH, Sheu JC, Chen DS, et al. Effective reduction of Helicobacter pylori infection after upper gastrointestinal endoscopy of mechanical washing of the endoscope. Hepatogastroenterology 1996;43:1660-1664.

25. Webb SF, Vall-Spinosa A. Outbreak of Serratia marcescens associated with the flexible bronchoscope. Chest 1975;68:703-708

26. Hussain SA. Fiberoptic bronchoscope-related outbreak of infection with Pseudomonas. Chest 1978;74:483.

27. Markovitz A. Inoculation by bronchoscopy. West I Med 1979;131:550.

28. Leers W-D. Disinfecting endoscopes: how not to transmit Mycobacterium tuberculosis by bronchoscopy. Can Med Assoc I $1980 ; 123: 275-280$.

29. Nelson KE, Larson PA, Schraufnagel DE, Jackson J. Transmission of tuberculosis by flexible fiberbronchoscopes. Am Rev Respir Dis 1983:127:97-100

30. Pappas SA, Schaaf DM, DiCostanzo MB, King FW, Sharp JT. Contamination of flexible fiberoptic bronchoscopes. Chest 1983;127:391392.

31. Wheeler PW, Lancaster D, Kaiser AB. Bronchopulmonary crosscolonization and infection related to mycobacterial contamination of suction valves of bronchoscopes. I Infect Dis 1989;159:954-958.

32. Agerton T, Valway S, Gore B, Pozsik C, Plikaytis B, Woodley C, et al. Transmission of a highly drug-resistant strain (strain W1) of Mycobacterium tuberculosis. Community outbreak and nosocomial transmission via a contaminated bronchoscope. JAMA 1997;278:1073-1077.

33. Blanc DS, Parret T, Janin B, Raselli P, Francioli P. Nosocomial infections and pseudoinfections from contaminated bronchoscopes: two-year follow up using molecular markers. Infect Control Hosp Epidemiol 1997;18:134-136.

34. Michele TM, Cronin WA, Graham NM, Dwyer DM, Pope DS, Harrington $\mathrm{S}$, et al. Transmission of Mycobacterium tuberculosis by a fiberoptic bronchoscope. Identification by DNA fingerprinting. $J A M A$ 1997;278:1093-1095.

35. Kramer MH, Krizek L, Gebel J, Kirsch A, Wegan E, Marklein G, et al Bronchoscopic transmission of Pseudomonas aeruginosa due to a conta- minated disinfectant solution from an automated dispenser unit. In Final Program of the 11th Annual Scientific Meeting of the Society of Healthcare Epidemiology of America; Toronto, Ontario, Canada; April 13, 2001. Abstract 118 .

36. Weinstein HJ, Bone RC, Ruth WE. Contamination of a fiberoptic bronchoscope with a Proteus species. Am Rev Respir Dis 1977;116:541-543.

37. Dawson DJ, Armstrong JG, Blacklock ZM. Mycobacterial crosscontamination of bronchoscopy specimens. Am Rev Respir Dis 1982;126:1095-1097.

38. Sammartino MT, Israel RH, Magnussen CR. Pseudomonas aeruginosa contamination of fibreoptic bronchoscopes. J Hosp Infect 1982;3:65-71.

39. Goldstein B, Abrutyn E. Pseudo-outbreak of Bacillus species: related to fibreoptic bronchoscopy. J Hosp Infect 1985;6:194-200.

40. Siegman-Igra Y, Inbar G, Campus A. A 'outbreak' of pulmonary pseudoinfection by Serratia marcescens. J Hosp Infect 1985;6:218-220.

41. Richardson AJ, Rothburn MM, Roberts C. Pseudo-outbreak of Bacillus species: related to fiberoptic bronchoscopy. I Hosp Infect 1986;7:208-210.

42. Hoffmann KK, Weber DJ, Rutala WA. Pseudoepidemic of Rhodotorula rubra in patients undergoing fiberoptic bronchoscopy. Infect Control Hosp Epidemiol 1989;10:511-514.

43. Nye K, Chadha DK, Hodgkin P, Bradley C, Hancox J, Wise R Mycobacterium chelone $i$ isolation from broncho-alveolar lavage fluid and its practical implications. J Hosp Infect 1990;16:257-260.

44. Centers for Disease Control and Prevention. Nosocomial infection and pseudoinfection from contaminated endoscopes and bronchoscopesWisconsin and Missouri. MMWR 1991;40:675-678.

45. Fraser VJ, Jones M, Murray PR, Medoff G, Zhang Y, Wallace RJ. Contamination of flexible fiberoptic bronchoscopes with $M y c o b a c t e r i u m$ chelonae linked to an automated bronchoscope disinfection machine. Am Rev Respir Dis 1992;145:853-855.

46. Gubler JGH, Salfinger M, von Graevenitz A. Pseudoepidemic of nontuberculous mycobacteria due to a contaminated bronchoscope cleaning machine. Chest 1992;101:1245-1249.

47. Nicolle LE, McLeod J, Romance L, Parker S, Paraskevas M. Pseudooutbreak of blastomycosis associated with contaminated bronchoscopes. Infect Control Hosp Epidemiol 1992;13:324.

48. Whitlock WL, Dietrich RA, Steimke EH, Tenholder MF. Rhodotorula rubra contamination in fiberoptic bronchoscopy. Chest 1992;102:1516 1519.

49. Bryce EA, Walker M, Bevan C, Smith JA. Contamination of bronchoscopes with Mycobacterium tuberculosis. Canadian Journal of Infection Control 1993;8:35-36.

50. Vandenbroucke-Grauls CMJE, Baars ACM, Visser MR, Hulstaert PF, Verhoef J. An outbreak of Serratia marcescens traced to a contaminated bronchoscope. J Hosp Infect 1993;23:263-270.

51. Bennett SN, Peterson DE, Johnson DR, Hall WN, Robinson-Dunn B, Dietrich S. Bronchoscopy-associated Mycobacterium xenopi pseudoinfections. Am J Respir Crit Care Med 1994;150:245-250.

52. Campagnaro RI, Teichtahl H, Dwyer B. A pseudoepidemic of Mycobacterium chelonae: contamination of a bronchoscope and autocleaner. Aust N Z J Med 1994;24:693-695.

53. Kolmos HJ, Lerche A, Kristoffersen K, Rosdahl VT, Pseudo-outbreak of Pseudomonas aeruginosa in HIV-infected patients undergoing fiberoptic bronchoscopy. Scand I Infect Dis 1994;26:653-657.

54. Maloney S, Welbel S, Daves B, Adams K, Becker S, Bland L et al. Mycobacterium abscessus pseudoinfection traced to an automated endoscope washer: utility of epidemiologic and laboratory investigation. $J$ Infect Dis 1994:169:1166-1169.

55. Peterson K, Bus N, Walter V, Chenoweth C. Pseudoepidemic of Mycobacterium abscessus associated with bronchoscopy. Infect Control Hosp Epidemiol 1994;15(suppl):P30. Abstract S32.

56. Hagan ME, Klotz SA, Bartholomew W, Potter L, Nelson M. A pseudoepidemic of Rhodotorula rubra: a marker for microbial contamination of the bronchoscope. Infect Control Hosp Epidemiol 1995;16:727-728.

57. Takigawa K, Fujita J, Negayama K, Terada S, Yamaji S, Kawanashi K, et al. Eradication of contaminating Mycobacterium chelonae from bronchofibrescopes and an automated bronchoscope disinfection machine. Respir Med 1995;89:423-427.

58. Wang HC, Liaw YS, Yand PC, Kuo SH, Luh KT. A pseudoepidemic of Mycobacterium chelonae infection caused by contamination of a fibreoptic bronchoscope suction channel. Eur Respir J 1995;8:1259-1262.

59. Mitchell DH, Hicks LJ, Chiew R, Montanaro JC, Chen SC Pseudoepidemic of Legionella pneumophila serogroup 6 associated with contaminated bronchoscopes. I Hosp Infect 1997;37:19-23.

60. Wallace RJ Jr, Brown BA, Griffith DE. Nosocomial outbreaks/pseudooutbreaks caused by nontuberculous mycobacteria. Annu Rev Microbiol 1998;52:453-490.

61. Centers for Disease Control and Prevention. Bronchoscopy-related infections and pseudoinfections-New York, 1996 and 1998. MMWR $1999 ; 48: 557-560$.

62. Strelczyk K Pseudo-outbreak of acid-fast bacilli. Am I Infect Control 
1999;27:18. Abstract.

63. Wilson SJ, Everts RJ, Kirkland KB, Sexton DJ. A pseudo-outbreak of Aurobasidium species lower respiratory tract infections caused by reuse of single-use stopcocks during bronchoscopy. Infect Control Hosp Epidemiol 2000;21:470-472.

64. Larson J, Lambert L, Stricof R, Ridzon R, Navin T. Mycobacterium tuberculosis contamination and potential exposure from a bronchoscope, Pennsylvania-2000. In: Final Program of the 11th Annual Scientific Meeting of the Society for Healthcare Epidemiology of America; Toronto, Ontario, Canada: April 1-3, 2001.

65. Mehta A, Minai OA. Infection control in the bronchoscopy suite. A review. Clin Chest Med 1999;20:19-32.

66. Steere AC, Corrales J, von Graevenitz A. A cluster of Mycobacterium gordonae isolates from bronchoscopy specimens. Am Rev Respir Dis 1979;120:214-216.

67. Schleupner CJ, Hamilton JR. A pseudoepidemic of pulmonary fungal infections related to fiberoptic bronchoscopy. Infect Control 1980;1:38-42.

68. Cox R, deBorja K, Bach MC. A pseudo-outbreak of Mycobacterium chelonae infections related to bronchoscopy. Infect Control Hosp Epidemiol 1997;18:136-137.

69. Southwick KI, Hoffmann K, Ferree K, Matthews J, Salfinger M. Cluster of tuberculosis cases in North Carolina: possible association with atomizer use. Am J Infect Control 2001;29:1-6.

70. Weber DJ, Rutala WA Occupational risks associated with the use of selected disinfectants and sterilants. In: Rutala WA, ed. Disinfection, Sterilization and Antisepsis in Health Care. Champlain, NY: Polyscience Publications; 1998:211-226.

71. Bradley CR, Babb JR. Endoscope decontamination: automated vs. man- ual. J Hosp Infect 1995;30(suppl):537-542.

72. Muscarella LF. Advantages and limitations of automatic flexible endoscope reprocessors. Am J Infect Control 1996;24:304-309.

73. Muscarella LF. Automatic flexible endoscope reprocessors. Gastrointest Endosc Clin N Am 2000;10:245-257.

74. Cooke RP, Rhymant-Morris A, Umasankar RS, Goddard SV. Bacteriafree water for automatic washer-disinfectors: an impossible dream? J Hosp Infect 1998;39:63-65.

75. Lynch DA, Porter C, Murphy L, Axon AT. Evaluation of four commercial automatic endoscope washing machines. Endoscopy 1992;24:766770.

76. Jackson FW, Ball MD. Correction of deficiencies in flexible fiberoptic sigmoidoscope cleaning and disinfection technique in family practice and internal medicine offices. Arch Intern Med 1997;6:578-582.

77. Orsi GB, Filocamo A, Di Stefano L, Tittobello A. Italian national survey of digestive endoscopy disinfection practices. Endoscopy 1997;29:732738.

78. Honeybourne D, Neumann CS. An audit of bronchoscopy practice in the United Kingdom: a survey of adherence to national guidelines. Thorax 1997;52:709-713.

79. Food and Drug Administration, Centers for Disease Control and Prevention. FDA and CDC public health advisory: infections from endoscopes inadequately reprocessed by an automated endoscope reprocessing system. September 10, 1999. http://fda.gov/cdrh/safety/ endoreprocess.html.

80. Society of Gastrointestinal Nurses and Associates. Standards for infection control and reprocessing of flexible gastrointestinal endoscopes. Gastroenterology Nursing 2000;23:172-179. 